\title{
PENINGKATAN MUTU PENDIDIKAN SMA MUHAMMADIYAH 2 SIDOARJO SEBAGAI SEKOLAH BERKATEGORI THE OUTSTANDING SCHOOL OF MUHAMMADIYAH
}

\author{
Hidayatulloh \\ Universitas Muhammadiyah Sidoarjo, Indonesia \\ E-mail: hidayatulloh69@gmail.com
}

\begin{abstract}
This article examines about improving the education quality of SMA Muhammadiyah 2 Sidoarjo as the Outstanding School of Muhammadiyah. This article reveals that the quality improvement of SMA Muhammadiyah 2 Sidoarjo was conducted through: the arrangement of school program and self evaluation, the reinforcement of vision, mission and education objective, the reinforcement of leadership and teamwork, the improvement of teachers and educators competence, the improvement learners quality input, the development of curriculum and learning, the development of school culture, the development of facilities and infrastructure, the development of community service, the cooperation of education and student exchange, the mobilization of education funding resources, the development of SIM, monitoring and evaluation, and education quality system. The management quality of SMA Muhammadiyah 2 Sidoarjo was run through input-process-output formula. The process of quality containes the process of quality planning, main process, supporting process, dan quality improvement process. Factors supporting the quality improvement are: Muhammadiyah's popular name, the doctrine of education quality improvement, the leadership of TORSIE paradigm, the school academicians' spirit of gaining achievement, the synergy of school academicians, the appropriate facilities, and the supports of all stakeholders.
\end{abstract}

Keywords: SMA Muhammadiyah 2 Sidoarjo; the Outstanding School of Muhammadiyah.

\section{Pendahuluan}

Perkembangan masyarakat dewasa ini membutuhkan layanan pendidikan Islam bermutu mengalami peningkatan secara signifikan, 
sehingga kehadiran lembaga pendidikan Islam yang bermutu adalah suatu keniscayaan, sebagaimana dinyatakan oleh Abdul Malik Fadjar bahwa "kehadiran lembaga pendidikan Islam yang berkualitas dalam berbagai jenis dan jenjang pendidikan sesungguhnya sangat diharapkan oleh berbagai pihak, terutama umat Islam. Bahkan kini terasa sebagai kebutuhan yang sangat mendesak terutama bagi kalangan Muslim kelas menengah ke atas yang secara kuantitatif terus meningkat". ${ }^{1}$

Dunia pendidikan di Indonesia masih menghadapi ragam persoalan, di mana salah satu persoalan yang sedang dihadapi adalah rendahnya mutu pendidikan pada setiap jenjang dan satuan pendidikan, khususnya pendidikan tingkat dasar dan menengah. Hal ini sebagaimana dilaporkan oleh beberapa lembaga internasional, antara lain: (1) UNESCO pada tahun 2012 melaporkan indeks pembangunan pendidikan di Indonesia berada di peringkat ke-64 dari 120 negara; (2) UNDP melaporkan IPM atau HDI Indonesia mengalami penurunan dari peringkat ke-108 pada 2010 menjadi peringkat ke-124 pada tahun 2012 dari 180 negara. Selanjutnya pada 14 Maret 2013 dilaporkan naik tiga peringkat menjadi urutan ke-121 dari 185 negara; ${ }^{2}$ dan (3) Penilaian PISA tahun 2012 memosisikan Indonesia pada urutan ke-64 dari 65 negara partisipan. ${ }^{3}$

Salah satu lembaga negara yang paling bertanggung jawab dalam bidang pendidikan di Indonesia adalah Kementerian Pendidikan dan Kebudayaan. Sejak tahun 2001 Kementerian Pendidikan Nasional telah melakukan evaluasi dan pengkajian tentang rendahnya mutu pendidikan di Indonesia. Dari hasil evaluasi dan pengkajian yang dilakukan itu disimpulkan ada tiga faktor penting yang mengakibatkan belum terwujudnya mutu pendidikan sebagaimana yang diharapkan. Ketiga faktor itu adalah: Pertama, kebijakan dan penyelenggaraan pendidikan nasional yang menggunakan pendekatan education production function atau input output analysis yang tidak dilaksanakan secara

\footnotetext{
1 Abdul Malik Fadjar, "Pengembangan Pendidikan Islam Yang Menjanjikan Masa Depan”, dalam Mudjia Rahardjo (ed.), Quo Vadis Pendidikan Islam, Pembacaan Realitas Pendidikan Islam, Sosial, dan Keagamaan (Malang: UIN Malang Press, 2006), 10.

2 Qori Delasera, "Kualitas Pendidikan Indonesia (Refleksi 2 Mei)", dalam http://edukasi.kompasiana. com/ 2013/05/03/kualitas-pendidikan-indonesiarefleksi-2-mei-html (16 Januari 2014).

3 Kopertis Wilayah XII, "Skor PISA: Posisi Indonesia Nyaris Jadi Juru Kunci", dalam http://www.kopertis12.or.id/2013/12/05/skor-pisa-posisi-indonesia-nyarisjadi-juru -kunci.html (7 Maret 2014).
} 
konsekuen. Penerapan pendekatan education production function terlalu berpusat pada input pendidikan dan kurang adanya perhatian pada proses pendidikan. Kedua, penyelenggaraan pendidikan dilakukan secara sentralistik, sehingga menjadikan sekolah sangat tergantung pada kebijakan dan/atau keputusan birokrasi di atasnya, yang kadangkadang kebijakan yang dikeluarkan tidak sesuai dengan kondisi yang ada di sekolah. Ketiga, peran serta masyarakat, khususnya orang tua/wali siswa, dipandang masih minim. Partisipasi masyarakat selama ini umumnya lebih banyak mendukung dana saja, tidak pada proses pendidikannya. ${ }^{4}$

Atas dasar faktor-faktor sebagaimana tersebut, maka Ditjen Dikdasmen Kemdiknas Republik Indonesia mengambil kebijakan strategis dalam meningkatkan mutu pendidikan di Indonesia melalui: (1) Manajemen peningkatan mutu berbasis sekolah (school based management); (2) Pendidikan berbasis pada partisipasi komunitas (community based education); (3) Penggunaan paradigma belajar (learning paradigm) yang akan menjadikan pelajar (learner) menjadi manusia yang diberdayakan; dan (4) Perluasan pendekatan Broad Based Education (BBE) dengan pembekalan keterampilan kecakapan hidup (life skill). ${ }^{5}$ Kebijakan strategis yang diambil Kemdiknas di atas memberikan ruang yang luas bagi lembaga pendidikan untuk melakukan inovasi dan mengembangkan kreativitas dalam mewujudkan keunggulan lembaga pendidikan.

Di lingkungan Muhammadiyah Jawa Timur terdapat tiga kategori sekolah unggul, yaitu: (1) The Inspiring School of Muhammadiyah, yakni sekolah-sekolah Muhammadiyah yang mempunyai semangat dan kemampuan untuk menjadi sekolah unggul; (2) The Excellent School of Mubammadiyah, yakni merupakan sekolah-sekolah Muhammadiyah yang unggul; dan (3) The Outstanding School of Mubammadiyah, yakni merupakan sekolah-sekolah Muhammadiyah yang dinilai sudah mengembangkan budaya mutu, dengan capaian selama empat tahun berturut-turut menduduki peringkat kesatu dalam kategori The Excellent School of Muhammadiyah. ${ }^{6}$

\footnotetext{
${ }^{4}$ Departemen Pendidikan Nasional, Manajemen Peningkatan Mutu Berbasis Sekolah, Konsep dan Pelaksanaan (Jakarta: Dirjen Dikdasmen, 2001), 1-3.

${ }^{5}$ Falah Yunus, "Manajemen Peningkatan Mutu Pendidikan", dalam http://www. geocities.ws/guruvalah/ Manaj Pening Mutu Pend.html (6 April 2014), 2-3.

${ }^{6}$ Biyanto (Ketua Majelis Dikdasmen PW Muhammadiyah Jawa Timur), Wawancara, Surabaya, 15 November 2013.
} 
Sampai dengan penelitian ini dilakukan sekolah/madrasah Muhammadiyah di Jawa Timur yang masuk kategori The Outstanding School of Muhammadiyah ada tiga sekolah, yaitu SD Muhammadiyah 4 Pucang Surabaya, SMP Muhammadiyah 5 Pucang Surabaya, dan SMA Muhammadiyah 2 Sidoarjo. Tiga sekolah tersebut ditetapkan Majelis Dikdasmen PWM Jawa Timur sebagai The Outstanding School of Mubammadiyah setelah meraih peringkat pertama sebagai The Excellent School of Mubammadiyah selama empat tahun berturut-turut. ${ }^{7}$

Keberadaan SMA Muhammadiyah 2 Sidoarjo sebagai sekolah berkategori The Outstanding School of Mubammadiyah di Jawa Timur menjadi salah satu sekolah unggulan pilihan masyarakat. Artikel ini berusaha untuk mendalami dan memformulasikan peningkatan mutu pendidikan di SMA Muhammadiyah 2 Sidoarjo. Dilatari oleh hal-hal sebagaimana diuraikan di atas, artikel ini mengangkat sebuah judul "Peningkatan Mutu Pendidikan di SMA Muhammadiyah 2 Sidoarjo sebagai Sekolah Berkategori The Outstanding School of Mubammadiyah (Studi Kasus di SMA Muhammadiyah 2 Sidoarjo". Ada beberapa penelitian sejenis dengan objek berbeda yang dilakukan oleh beberapa akademisi, antara lain: Karwanto, ${ }^{8}$ Achmad Supriyanto, ${ }^{9}$ AB. Musyafa' Fathoni, ${ }^{10}$ Sri Uchtiawati, ${ }^{11}$ dan lain-lain. Kesemuanya berbeda dengan fokus yang penulis teliti.

\section{Gambaran Umum SMA Muhammadiyah 2 Sidoarjo}

SMA Muhammadiyah 2 Sidoarjo didirikan pada tahun 1976 oleh Bagian Pendidikan Dasar dan Menengah (Dikdasmen) Pimpinan Cabang Muhammadiyah Sidoarjo. Pada tahun pertama hanya ada enam

\footnotetext{
${ }^{7}$ Ibid.

${ }^{8}$ Karwanto, "Ketrampilan Manajerial Peningkatan Keunggulan Pembelajaran: Studi Multi Kasus pada Tiga SMA Unggulan di Kota Semarang" (Disertasi--Program Studi Manajemen Pendidikan, Program Pascasarjana Universitas Negeri Malang, 2009).

9 Achmad Supriyanto, "Implementasi Total Quality Management dalam Sistem Manajemen Mutu Pembelajaran di Institusi Pendidikan", Cakrawala Pendidikan: Jurnal Ilmiah Pendidikan, Vol. 30, No. 1 (2011).

10 AB. Musyafa' Fathoni, "Peningkatan Kualitas Pendidikan Melalui Sistem Penjaminan Mutu: Studi Multisitus di SD Al Falah Tropodo 2 Sidoarjo, SDIT Bina Insani Kediri, dan SDIT Al-Hikmah Blitar" (Disertasi--Program Studi Manajemen Pendidikan, Program Pascasarjana Universitas Negeri Malang, 2009).

11 Sri Uchtiawati, "Penjaminan Mutu Pendidikan pada Perguruan Tinggi Muhmmadiyah di Jawa Timur: Studi Multisitus pada Universitas Sukiyanto, Universitas Suherman, dan Universitas Madjedi" (Disertasi--Program Studi Manajemen Pendidikan Program Pascasarjana Universitas Negeri Malang, 2010).
} 
pendaftar, menempati lokal SMP Muhammadiyah 1 Sidoarjo di Jasem Sidoarjo. Setelah berjalan dua bulan pindah ke SD Muhammadiyah 1 Sidoarjo. Tiga bulan berikutnya kegiatan pembelajaran berpindah ke lokasi SMA Muhammadiyah 2 Sidoarjo sekarang. Dengan berbekal disiplin yang tinggi dan kepercayaan masyarakat pada tahun ke tiga siswanya menjadi 84 anak.

Pada tahun kedua bertambah satu kelas, tahun ketiga bertambah lagi satu kelas, dan seterusnya dari tahun ke tahun mengalami pertambahan secara signifikan, hingga pada tahun pelajaran 1999/2000 jumlah siswanya menjadi 982 siswa yang tersebar ke dalam 21 kelas (kelas I, II dan III masing-masing paralel 7 kelas), kemudian pada tahun pelajaran 2005/2006 jumlah siswanya bertambah menjadi 1.228 siswa yang tersebar ke dalam 28 kelas (kelas I ada 10 kelas paralel, kelas II dan III masing-masing ada 9 kelas paralel). Sampai dengan dilakukannya penelitian ini, tahun pelajaran 2014/2015 terdapat 39 kelas (kelas X ada 14 kelas paralel, kelas XI ada 12 kelas paralel, dan XII ada 13 kelas paralel) dengan jumlah siswa seluruhnya sebanyak 1.331 siswa.

Untuk mendidik dan membina peserta didik yang jumlahnya lebih dari 1300 peserta didik tersebut SMA Muhammadiyah 2 Sidoarjo memiliki 68 (enam puluh delapan) orang guru, terdiri dari 63 (enam puluh tiga) guru mata pelajaran dan lima guru bimbingan dan konseling (BK). Dilihat dari statusnya, terdiri dari 10 (sepuluh) guru DPK, 31 (tiga puluh satu) guru tetap, dan 27 (dua puluh tujuh) guru tidak tetap. Untuk mendukung proses pelayanan SMA Muhammadiyah 2 Sidoarjo memberdayakan 47 karyawan, terdiri dari 45 orang yang bertugas di sekolah, satu orang yang bertugas di Majelis Dikdasmen Pimpinan Daerah Muhammadiyah Sidoarjo, dan satu orang yang bertugas di Majelis Dikdasmen Pimpinan Wilayah Muhammadiyah Jawa Timur. ${ }^{12}$

Dalam kurun waktu 39 tahun sejak sekolah ini berdiri, SMA Muhammadiyah 2 Sidoarjo telah mengalami lima kali masa kepemimpinan. Dari lima kali masa kepemimpinan itu SMA Muhammadiyah 2 Sidoarjo mengalami pengembangan dan pembaharuan (develop and reform) di berbagai bidang, baik sarana prasarana sekolah, kurikulum pendidikan dan pembelajaran, maupun sumber daya pelaksananya. Dari usaha melakukan pengembangan dan

12 Berdasarkan data dokumentasi dari Bagian Kepegawaian yang ada di Tata Usaha SMA Muhammadiyah 2 Sidoarjo, diambil tanggal 30 Desember 2014. 
pembaharuan di berbagai bidang itu, berdasarkan penjenjangan akreditasi pada 2005 SMA Muhammadiyah 2 Sidoarjo telah terakreditasi A dengan nilai 93,73 dan pada 2010 mengikuti akreditasi ulang dengan hasil terakreditasi A dengan nilai 97. Di samping itu sejak tahun pelajaran 2009/2010 sekolah ini ditetapkan oleh Direktorat Pembinaan SMA Departemen Pendidikan Nasional sebagai Rintisan Sekolah Bertaraf Internasional (RSBI). Dalam rangka mendapatkan legitimasi penerapan manajemen mutu di sekolah, maka pada 2011 SMA Muhammadiyah Sidoarjo tersertifikasi ISO 9001:2008 dari URS, selanjutnya setiap tahun dilakukan audit internal maupun audit eksternal.

Perkembangan SMA Muhammadiyah 2 Sidoarjo telah melahirkan berbagai prestasi dan penghargaan di bidang akademik dan nonakademik, mulai dari tingkat lokal sampai internasional. Sekolah ini mengalami kemajuan di berbagai bidang dan cukup sering mendapatkan apresiasi dan penghargaan dari berbagai pihak, baik negeri maupun swasta, sehingga tidak salah kalau kemudian banyak tokoh yang menyatakan bahwa SMA Muhammadiyah 2 Sidoarjo ini adalah sekolah unggulan dan menjadi salah satu sekolah terbaik di Indonesia.

Berbagai prestasi dan penghargaan telah diraih SMA Muhammadiyah 2 Sidoarjo, di bidang akademik dan non-akademik, mulai tingkat lokal sampai dengan tingkat nasional dan internasional. Di lingkungan Muhammadiyah Jawa Timur, selama empat tahun berturut-turut (2008, 2009, 2010, dan 2011), SMA Muhammadiyah 2 Sidoarjo menempati Peringkat Ke-Satu Sekolah Unggul Muhammadiyah (The Axcellent School of Mubammadiyah) di Jawa Timur. Atas prestasinya secara berturut-turut selama empat tahun sebagai The Excellent School of Mubammadiyah itu, maka pada tahun 2011 SMA Muhammadiyah 2 Sidoarjo ditetapkan sebagai The Outstanding School of Mubammadiyah. Predikat sebagai sekolah unggul berkategori The Outstanding School of Mubammadiyab ini disandang oleh SMA Muhammadiyah 2 Sidoarjo sampai sekarang.

Berbagai prestasi SMA Muhammadiyah 2 Sidoarjo di atas mengantarkan sekolah ini menjadi sekolah unggulan dan mendapatkan pengakuan, apresiasi, dan penghargaan dari berbagai kalangan, baik dari tokoh Muhammadiyah, tokoh pendidikan, pemerintah, anggota legislatif, maupun alumni. 


\section{Peningkatan dan Manajemen Mutu Pendidikan di SMA Muhammadiyah 2 Sidoarjo}

SMA Muhammadiyah 2 Sidoarjo selalu melakukan pengembangan dan pembaruan di berbagai bidang, baik sarana prasarana, kurikulum pendidikan, iklim akademik dan spiritualitas keislaman, sistem layanan, maupun sumber daya pelaksananya. Upaya pengembangan dan pembaharuan di berbagai bidang itu dimaksudkan untuk meningkatkan mutu SMA Muhammadiyah 2 Sidoarjo.

Upaya peningkatan mutu pendidikan di SMA Muhammadiyah 2 Sidoarjo dititikberatkan pada empat belas langkah, yaitu: (1) Melakukan evaluasi diri sekolah (EDS) dan penyusunan program kerja sekolah; (2) Penguatan visi, misi, dan tujuan pendidikan; (3) Penguatan kepemimpinan dan teamwork; (4) Peningkatan kompetensi pendidik dan tenaga kependidikan, (5) Peningkatan mutu input peserta didik; (6) Pengembangan kurikulum dan pembelajaran; (7) Pengembangan kultur sekolah; (8) Pengembangan sarana dan prasarana pendidikan; (9) Penciptaan lingkungan yang aman dan tertib; (10) Pengembangan pengabdian kepada masyarakat; (11) Kerjasama pendidikan dan pertukaran pelajar; (12) Mobilisasi sumber dana pendidikan; (13) Pengembangan sistem informasi manajemen (SIM); (14) Monitoring dan evaluasi; dan (15) Pengembangan sistem manajemen mutu SMA Muhammadiyah 2 Sidoarjo.

Pelaksanaan manajemen mutu SMA Muhammadiyah 2 Sidoarjo melibatkan dua belas unit kerja yang memenuhi standar mutu, yaitu: (1) Unit kerja lembaga penjaminan mutu sebagai wakil manajemen mutu, (2) Unit kerja kurikulum, (3) Unit kerja kesiswaan, (4) Unit kerja ISMUBA (al-Islam, Kemuhammadiyahan, dan Bahasa Arab), (5) Unit kerja sarana prasarana, (6) Unit kerja hubungan masyarakat dan kerjasama, (7) Unit kerja tata usaha, (8) Unit kerja keuangan, (9) Unit kerja laboratorium, (10) Unit kerja perpustakaan, (11) Unit kerja Bimbingan dan Konseling, dan (12) Unit kerja usaha kesehatan sekolah.

Model manajemen mutu SMA Muhammadiyah 2 Sidoarjo menggambarkan suatu proses usaha yang berlangsung dalam tiga bagian yaitu: (1) Input pendidikan, (2) Proses mutu pendidikan, dan (3) Output pendidikan. ${ }^{13}$

\footnotetext{
13 SMA Muhammadiyah 2 Sidoarjo, Manual Mutu (Sidoarjo: Lembaga Penjaminan Mutu, 2013), 9.
} 
Pertama, Input Pendidikan merupakan hal yang harus ada atau diadakan sebelum proses mutu dilaksanakan, terdiri dari: (a) Regulasi pendidikan; (b) Kebijakan dan program Majelis Dikdasmen tentang peningkatan mutu pendidikan; (c) Visi, misi, tujuan, dan kebijakan mutu SMA Muhammadiyah 2 Sidoarjo; (d) Program kerja SMA Muhammadiyah 2 Sidoarjo; dan (e) Sumber daya yang siap digerakkan. $^{14}$

Kedua, Proses Mutu Pendidikan, mengikuti standar ISO 9001:2008 dengan empat proses mutu, yaitu: (1) Proses perencanaan mutu, di mana ditetapkannya dokumen sistem manajemen mutu, terdiri dari (a) Kebijakan mutu; (b) Sasaran mutu; (c) Manual mutu; dan (d) Standar operasional prosedur (SOP) dan Instruksi Kerja (IK). (2) Proses inti dalam sistem manajemen mutu SMA Muhammadiyah 2 Sidoarjo terdiri dari proses kegiatan belajar mengajar, proses dakwah, dan pengaderan (3) Proses pendukung. Proses ini dilakukan untuk mendukung pelaksanaan proses inti, meliputi: pengendalian dokumen, pengelolaan keuangan, pengelolaan tata usaha (administrasi akademik dan kesiswaan, administrasi umum, administrasi kerumahtanggaan, dan administrasi kepegawaian), pengelolaan sarana dan prasarana, pengelolaan kesiswaan, pengelolaan bimbingan konseling, pengelolaan perpustakaan, pengelolaan laboratorium, pengelolaan usaha kesehatan sekolah, pengelolaan unit usaha sekolah, pengelolaan keamanan, dan pengelolaan kebersihan, dan (4) Proses peningkatan mutu. Proses ini dilakukan untuk mengukur dan meninjau efektivitas dari penerapan sistem manajemen mutu yang dijalankan serta mengambil tindakan yang diperlukan untuk melakukan peningkatan kinerja dalam prosesproses yang ada. Proses peningkatan mutu meliputi kegiatan audit mutu internal, rapat tinjauan manajemen, penanganan keluhan pelanggan, pengukuran kepuasan pelanggan, analisis data, serta tindakan koreksi dan pencegahan. ${ }^{15}$

Ketiga, Output Pendidikan. Output ini merupakan kinerja sekolah yang menggambarkan tentang prestasi sekolah yang dihasilkan dari serangkaian proses atau perilaku sekolah. Dari hasil observasi, wawancara, dan telaah dokumen relevan yang telah diuraikan pada bagian upaya peningkatan mutu dan manajemen mutu pendidikan,

\footnotetext{
${ }^{14}$ Diolah dari hasil telaah manual mutu dan wawancara dengan pimpinan dan wakil manajemen mutu SMA Muhammadiyah 2 Sidoarjo tanggal 19 Mei 2015.

15 SMA Muhammadiyah 2 Sidoarjo, Manual Mutu, 10-21.
} 
maka dapat dirumuskan output pendidikan yang dihasilkan oleh SMA Muhammadiyah 2 Sidoarjo, sebagai berikut:

a. Menghasilkan lulusan yang taat beragama, berakhlak mulia, dan menguasai ilmu pengetahuan.

b. Meningkatnya prestasi hasil ujian nasional (UN) dan jumlah lulusan yang diterima di Perguruan Tinggi Negeri (PTN) dan Perguruan Tinggi Swasta (PTS) Unggulan.

c. Meningkatnya prestasi dibidang olimpiade dan kejuaraan, meliputi prestasi lembaga, prestasi guru, dan prestasi siswa, mulai tingkat lokal sampai dengan internasional.

d. Meningkatnya pengakuan dan apresiasi atas prestasi dan keunggulan SMA Muhammadiyah 2 Sidoarjo dari Pimpinan Persyarikatan Muhammadiyah, Pemerintah, Lembaga Pendidikan Tinggi, tokoh pendidikan, tokoh masyarakat, orang tua/wali peserta didik, dan alumni SMA Muhammadiyah 2 Sidoarjo.

\section{Keunggulan SMA Muhammadiyah 2 Sidoarjo}

Dari hasil penelitian yang dilakukan ditemukan delapan belas indikator keunggulan SMA Muhammadiyah 2 Sidoarjo, sebagai berikut:

1. Memiliki rumusan visi, misi, tujuan, dan program peningkatan mutu pendidikan.

2. Memiliki kebijakan dan sasaran mutu pendidikan.

3. Mengembangkan model kepemimpinan berparadigma TORSIE dan teamwork yang kuat.

4. Kompetensi dan komitmen guru dan tenaga kependidikan yang tinggi.

5. Memiliki sarana prasarana dan sistem informasi manajemen (SIM) yang kuat.

6. Menerapkan sistem seleksi penerimaan peserta didik baru.

7. Mengembangkan proses pendidikan dan pembelajaran yang menyenangkan.

8. Tersedia lembaga organisasi kesiswaan dan kegiatan ekstrakurikuler.

9. Penguatan karakter dan budaya mutu sekolah, terdiri dari: (a) penegakan kedisiplinan bagi guru, karyawan, dan peserta didik, (b) pelibatan warga sekolah dalam mewujudkan lingkungan sekolah yang bersih, rapi, indah, nyaman, dan modern, (c) gerakan penguatan spiritualitas keislaman, dan (d) menumbuhkan semangat keunggulan. 
10. Program beasiswa bagi peserta didik, guru, dan karyawan.

11. Tata kelola keuangan yang kuat.

12. Brand dan diferensiasi sekolah yang dikenalkan kepada masyarakat luas, yaitu: (a) SMAMDA The Real School; (b) SMAMDA The School of Champions; (c) SMAMDA The School of Holistic Education), (d) SMAMDA The School of Character; dan (e) SMAMDA The Outstanding School of Mubammadiyah. ${ }^{16}$

13. Tingginya partisipasi orang tua/wali peserta didik dalam peningkatan mutu pendidikan.

14. Prestasi yang dicapai sekolah dalam bidang akademik dan nonakademik pada level nasional dan internasional.

15. Lingkungan sekolah yang aman dan teratur.

16. Penerapan Sistem Manajemen Mutu Yang Berdampak terhadap Peningkatan Mutu Sekolah.

17. Orientasi internasional (International Orientation)

18. Apresiasi dan penghargaan yang diberikan oleh berbagai lembaga dan perorangan kepada SMA Muhammadiyah 2 Sidoarjo.

\section{Faktor-Faktor Yang Mempengaruhi Upaya Peningkatan Mutu Pendidikan di SMA Muhammadiyah 2 Sidoarjo}

\section{Faktor Pendukung}

a. Nama besar Muhammadiyah yang menjadi pelopor pendidikan modern di Indonesia, sehingga tidak asing dan sangat menarik bagi masyarakat luas;

b. Adanya doktrin yang kuat dan tegas di dalam Muhammadiyah yang menyatakan bahwa pimpinan sekolah harus mampu meningkatkan dan mengembangkan mutu pendidikan Muhammadiyah;

c. Adanya dukungan dan kepercayaan Pimpinan Persyarikatan Muhammadiyah dan Majelis Dikdasmen Pimpinan Wilayah Muhammadiyah Jawa Timur yang menjadikan SMA Muhammadiyah 2 Sidoarjo sebagai pusat pengembangan sekolah-sekolah Muhammadiyah di Jawa Timur;

d. Adanya Pengembangan kepemimpinan sekolah berparadigma TORSIE (Trust, Openness, Realization, Synergy, Interdepence, and Empowering), sehingga mampu membangun teamwork yang kuat dan kompak dalam meningkatn mutu pendidikan;

\footnotetext{
${ }^{16}$ Pengenalan brand SMA Muhammadiyah 2 Sidoarjo kapada masyarakat luas ini bisa kita temukan di www.smamda.ac.id, buku-buku yang diterbitkan, dan berbagai sarana promosi lainnya.
} 
e. Adanya keinginan dan semangat yang sangat tinggi dari sebagian besar warga sekolah untuk membesarkan dan memajukan SMA Muhammadiyah 2 Sidoarjo menjadi sekolah yang unggul dan berprestasi;

f. Adanya kekompakan dari pimpinan sekolah, guru, karyawan, peserta didik, dan orang tua/wali peserta didik di dalam bersinergi atau melakukan kerjasama yang produktif dalam mengembangkan dan memajukan SMA Muhammadiyah 2 Sidoarjo menjadi sekolah yang unggul dan berprestasi;

g. Adanya fasilitas prasarana dan sarana yang memadai, termasuk dukungan teknologi informasi yang memudahkan dan mempercepat penyelesaian pekerjaan;

h. Adanya dukungan dana yang cukup memadai dalam memenuhi seluruh kebutuhan sekolah, baik yang menyangkut biaya operasional sekolah, peningkatan SDM, dan pengembangan sarana dan prasarana sekolah;

i. Adanya kepercayaan dan dukungan Pemerintah Pusat dan Daerah, terutama Direktorat Pembinaan SMA dan Dinas Pendidikan Provinsi Jawa Timur dan Kabupaten Sidoarjo, dalam memberikan dorongan dan bantuan untuk kebesaran dan kemajuan SMA Muhammadiyah 2 Sidoarjo;

j. Adanya dukungan dari mitra SMA Muhammadiyah 2 Sidoarjo, antara lain: Lembaga ISO 9001:2008, Bank BSM, dan Perguruan Tinggi Negeri dan Swasta di Indonesia yang menerima lulusan SMA Muhammadiyah 2 Sidoarjo; dan

k. Adanya penilaian yang bagus dari pemerintah, pimpinan Persyarikatan, tokoh pendidikan, tokoh masyarakat, orang tua peserta didik, peserta didik, dan alumni terhadap SMA Muhammadiyah 2 Sidoarjo sebagai salah satu sekolah unggulan di Indonesia.

\section{Faktor Penghambat}

a. Masih ada sebagian warga sekolah yang belum komitmen dan serius dalam menjalankan program peningkatan mutu pendidikan di sekolah.

b. Sebagian kecil guru dan karyawan belum bekerja sesuai dengan standar yang ditetapkan oleh sekolah. Mislanya tentang keharusan bagi semua guru dan karyawan dalam mengikuti salat berjemaah di masjid an-Nur, jam datang di sekolah dan jam pembelajaran di 
kelas yang dilakukan oleh guru, serta masalah kontinuitas standar kebersihan di sekolah yang ditangani bagian kebersihan.

c. Masih ada sebagian orang tua/wali peserta didik yang kurang memberi contoh baik bagi anaknya di rumah, sehingga apa yang diberikan dan dibiasakan di sekolah tidak didukung dengan kebiasaan di rumah, misalanya masalah kebiasaan membaca alQur'ân dan salat berjemaah.

d. Perkembangan pola hidup yang sangat longgar di masyarakat dan kurangnya perhatian orang tua/wali peserta didik ketika anaknya di luar rumah.

e. Penilaian sebagian masyarakat terhadap SMA Muhammadiyah 2 Sidoarjo adalah sekolah yang mahal dan kurang dipahaminya kebijakan pemberian beasiswa bagi peserta didik dari keluarga kurang mampu.

\section{Peningkatan Mutu SMA Muhammadiyah 2 Sidoarjo}

Upaya peningkatan mutu SMA Muhammadiyah 2 Sidoarjo diwujudkan dalam 15 langkah, yaitu: (1) Melakukan evaluasi diri sekolah (EDS) dan penyusunan program sekolah, (2) Penguatan visi, misi, dan tujuan pendidikan, (3) Penguatan kepemimpinan dan teamwork, (4) Peningkatan kompetensi pendidik dan tenaga kependidikan, (5) Peningkatan mutu input peserta didik, (6) Pengembangan kurikulum dan pembelajaran, (7) Pengembangan kultur sekolah, (8) Pengembangan sarana dan prasarana pendidikan, (9) Penciptaan lingkungan yang aman dan tertib, (10) Pengembangan pengabdian kepada masyarakat, (11) Kerjasama pendidikan dan pertukaran pelajar, (12) Mobilisasi sumber dana pendidikan, (13) Pengembangan Sistem Informasi Manajemen, (14) Monitoring dan evaluasi, dan (15) Pengembangan sistem manajemen mutu SMA Muhammadiyah 2 Sidoarjo.

Dari 15 langkah peningkatan mutu tersebut, jika dikaitkan dengan beberapa konsep atau teori peningkatan mutu pendidikan yang dikemukakan oleh para ahli, maka kita menemukan beberapa kesamaan dan perbedaan. Zamroni menyatakan bahwa peningkatan mutu pendidikan di tingkat sekolah dan kelas dapat dicapai dengan menjalankan 8 langkah, yaitu: (1) Melakukan school review; (2) Menyusun visi, misi, strategi, dan program kerja; (3) Memperluas kepemimpinan partisipatif; (4) Melakukan intervensi pada berbagai level; (5) Mengembangkan kultur sekolah; (6) Meningkatkan 
kemampuan guru; (7) Memobilisasi sumber dana; dan (8) Melakukan monitoring dan evaluasi. ${ }^{17}$

Dalam perspektif yang berbeda, Syafaruddin menyatakan bahwa peningkatan mutu pendidikan di tingkat sekolah dapat dicapai dengan melakukan 8 hal juga, yaitu: (1) Menyamakan komitmen mutu oleh kepala sekolah; (2) Mengusahakan adanya program peningkatan mutu sekolah; (3) Meningkatkan pelayanan administrasi sekolah; (4) Kepemimpinan kepala sekolah yang efektif; (5) Ada standar mutu lulusan; (6) Jaringan kerja sama yang baik dan luas; (7) Penataan organisasi sekolah yang baik; dan (8) Menciptakan iklim dan budaya sekolah yang kondusif. ${ }^{18}$ Dalam konsep sekolah bermutu yang dirumuskan oleh Kementerian Pendidikan Nasional, menyatakan bahwa proses pendidikan yang bermutu memiliki 14 karakteristik, yaitu: (1) Efektivitas proses belajar mengajar tinggi, (2) Kepemimpinan sekolah yang kuat, (3) Pengelolaan tenaga kependidikan secara efektif, (4) Sekolah memiliki lingkungan yang aman dan tertib, (5) Sekolah memiliki budaya mutu, (6) Sekolah memiliki teamwork yang kompak, cerdas, dan dinamis, (7) Sekolah memiliki kemandirian, (8) Partisipasi yang tinggi dari warga sekolah dan masyarakat, (9) Sekolah memiliki transparansi manajemen, (10) Sekolah memiliki kemauan untuk berubah, (11) Sekolah melakukan evaluasi dan perbaikan secara berkelanjutan, (12) Sekolah responsif dan antisipatif terhadap kebutuhan, (13) Sekolah memiliki komunikasi yang baik, dan (14) Sekolah memiliki akuntabilitas. ${ }^{19}$

Dari delapan hal yang dikemukakan oleh Syafaruddin dan 14 karakteristik sekolah bermutu yang dirumuskan oleh Kementerian Pendidikan Nasional tersebut secara implisit ada kesesuaiannya dengan upaya peningkatan mutu pendidikan di SMA Muhammadiyah 2 Sidoarjo. Dengan demikian maka 15 langkah upaya peningkatan mutu pendidikan di SMA Muhammadiyah 2 Sidoarjo tersebut merupakan pengembangan konsep dan teori peningkatan mutu pendidikan yang ada sebelumnya.

17 Zamroni, Meningkatkan Mutu Sekolah, Teori, Strategi, dan Prosedur (Jakarta: PSAP Muhammadiyah, 2007), 91-92.

18 Syafaruddin, Manajemen Lembaga Pendidikan Islam (Jakarta: Ciputat Press, 2005), 288.

${ }^{19}$ Depdiknas, Panduan Manajemen Sekolah (Jakarta: Dirjen Dikdasmen, 2000), 25-26. 


\section{Manajemen Mutu SMA Muhammadiyah 2 Sidoarjo}

Manajemen mutu SMA Muhammadiyah 2 Sidoarjo mengikuti pola input-proses-output dengan memberikan penguatan pada prosesnya. Input pendidikan terdiri dari: (1) Regulasi pendidikan; (2) Kebijakan dan program peningkatan mutu pendidikan Muhammadiyah; (3) Visi, misi, tujuan, dan kebijakan mutu SMA Muhammadiyah 2 Sidoarjo; (4) Program kerja SMA Muhammadiyah 2 Sidoarjo; dan (5) Sumber daya yang siap digerakkan.

Proses mutu pendidikan di SMA Muhammadiyah 2 Sidoarjo dijalankan dengan empat tahapan proses, yaitu: (1) Proses perencanaan mutu, (2) Proses inti, (3) Proses pendukung, dan (4) Proses peningkatan mutu.

1. Proses perencanaan mutu, terdiri dari: (a) kebijakan mutu, (b) sasaran mutu, (c) manual mutu, dan (d) standar operasional prosedur dan instruksi kerja.

2. Proses inti, terdiri dari: (a) proses kegiatan belajar mengajar, (b) proses dakwah, dan (c) proses pengaderan. Semua proses inti dilakukan dengan empat tahapan, yaitu perencanaan, pelaksanaan, evaluasi, dan pelaporan.

3. Proses pendukung terdiri dari: (a) pengendalian dokumen, (b) pengendalian catatan mutu, (c) pengelolaan keuangan, (d) pengelolaan tata usaha (administrasi akademik dan kesiswaan, administrasi umum, administrasi kepegawaian, dan administrasi kerumah tanggaan), (e) pengelolaan sarana dan prasarana, (f) pengelolaan kesiswaan, (g) pengelolaan bimbingan konseling, (h) Pengelolaan perpustakaan, (i) Pengelolaan laboratorium, (j) Pengelolaan usaha kesehatan sekolah, $(\mathrm{k})$ pengelolaan unit usaha sekolah, (l) pengelolaan keamanan, dan (m) pengelolaan kebersihan.

4. Proses peningkatan mutu, meliputi: (a) Kegiatan audit mutu internal, (b) Rapat tinjauan manajemen, (c) Penanganan keluhan pelanggan, (d) Pengukuran kepuasan pelanggan dan analisis data, dan (e) Tindakan koreksi dan pencegahan.

Semua proses dalam manajemen mutu di SMA Muhammadiyah 2 Sidoarjo, mulai dari perencanaan mutu sampai dengan peningkatan mutu, semuanya diorientasikan pada peningkatan mutu pendidikan dan kepuasan pelanggan sekolah, baik pelanggan internal maupun pelanggan eksternal, yang didasarkan pada nilai-nilai Islam. 
Proses mutu di SMA Muhammadiyah 2 Sidoarjo memperkuat dari konsep proses mutu yang dikemukakan oleh Joseph M. Juran yang memperkenalkan tiga proses mutu, yaitu: (1) Quality planning, (2) Quality control, dan (3) Quality improvement.20 Keduanya memandang sangat penting membuat perencanaan yang bermutu, melaksanaan kontrol yang bermutu, dan melakukan peningkatan mutu secara berkelanjutan. Perbedaanya adalah proses mutu di SMA Muhammadiyah 2 Sidoarjo diarahkan untuk meningkatkan mutu pendidikan dan kepuasan pelanggan yang didasarkan pada nilai-nilai Islam.

Proses perbaikan secara terus-menerus di SMA Muhammadiyah 2 Sidoarjo menggunakan istilah proses peningkatan mutu, yang terdiri dari: audit mutu internal, rapat tinjauan manajemen, penanganan keluhan pelanggan, pengukuran kepuasan pelanggan dan analisis data, serta tindakan koreksi dan pencegahan. Proses ini menggambarkan perbaikan berkelanjutan dengan menjalankan siklus Plan-Do-Check-Act (PDCA) seperti yang dikemukakan oleh William Edwards Deming, seorang ahli manajemen kualitas dari Amerika Serikat. Dickson Kho menyebut PDCA merupakan suatu siklus peningkatan proses (process improvement) yang berkesinambungan atau secara terus-menerus yang tidak ada akhirnya.

Proses perbaikan dan peningkatan mutu secara terus-menerus yang berjalan di SMA Muhammadiyah 2 Sidoarjo dituangkan dalam teks line "SMAMDA Continuous Inprovement". Semangat perbaikan dan peningkatan secara terus-menerus dalam manajemen mutu pendidikan ini sejalan dengan firman Allah dalam surat al-Hashr ayat 18 dan surat al-Ḍuhâ ayat 3 .

Proses manajemen mutu pendidikan di SMA Muhammadiyah 2 Sidoarjo melibatkan seluruh unit kerja. Proses ini memperkuat pendapat A.R. Tenner dan I. J. DeToro, yang menyatakan ada tiga cara yang perlu dilakukan dalam perbaikan berkelanjutan, yaitu: (1) Customer focus; (2) Improvement process; dan (3) Total involvement. ${ }^{21}$ Keterlibatan masing-masing unit kerja dalam peningkatan mutu pendidikan diorganisasikan dengan rapi dan kokoh, hal ini sejalan dengan spirit dalam dalam al-Qur'ân surat al-Ṣaff ayat 4.

Dari input pendidikan yang bermutu, dilanjutkan dengan proses

${ }^{20}$ Edward Sallis, Total Quality Management in Education (London: Kogan Page, 1993), $52-53$.

${ }^{21}$ Supriyanto, "Implementasi Total Quality Manajegement", 18. 
mutu pendidikan, maka bisa diharapkan output pendidikan yang bermutu pula. Output pendidikan yang dihasilkan oleh SMA Muhammadiyah 2 Sidoarjo, sebagai berikut: (a) Terbangunnya tradisi akademik dan spiritualitas keislaman dikalangan guru, karyawan, dan peserta didik, (b) Meningkatnya kompetensi guru dalam melaksanakan pendidikan dan pembelajaran di sekolah, (c) Meningkatnya kedisiplinan, ketertiban, dan kesungguhan guru, karyawan, dan peserta didik dalam meningkatkan mutu dan prestasi sekolah, (d) Meningkatnya prestasi hasil ujian nasional (UN) dan jumlah lulusan yang diterima di Perguruan Tinggi Negeri (PTN) dan Perguruan Tinggi Swasta (PTS) Unggulan, (e) Meningkatnya prestasi sekolah, meliputi prestasi lembaga, prestasi guru, dan prestasi siswa, mulai tingkat lokal sampai dengan internasional, dan (f) Meningkatnya pengakuan dan apresiasi atas prestasi dan keunggulan SMA Muhammadiyah 2 Sidoarjo dari dari berbagai kalangan.

Dari pembahasan manajemen mutu SMA Muhammadiyah 2 Sidoarjo di atas, mulai dari input pendidikan, dilanjutkan dengan proses mutu pendidikan, dan akhirnya menghasilkan output pendidikan, maka dapat dikembangkan model manajemen mutu pendidikan seperti ditunjukkan dalam gambar 5.1 di bawah ini.

\section{Gambar 5.1}

Model Manajemen Mutu Pendidikan

SMA Muhammadiyah 2 Sidoarjo

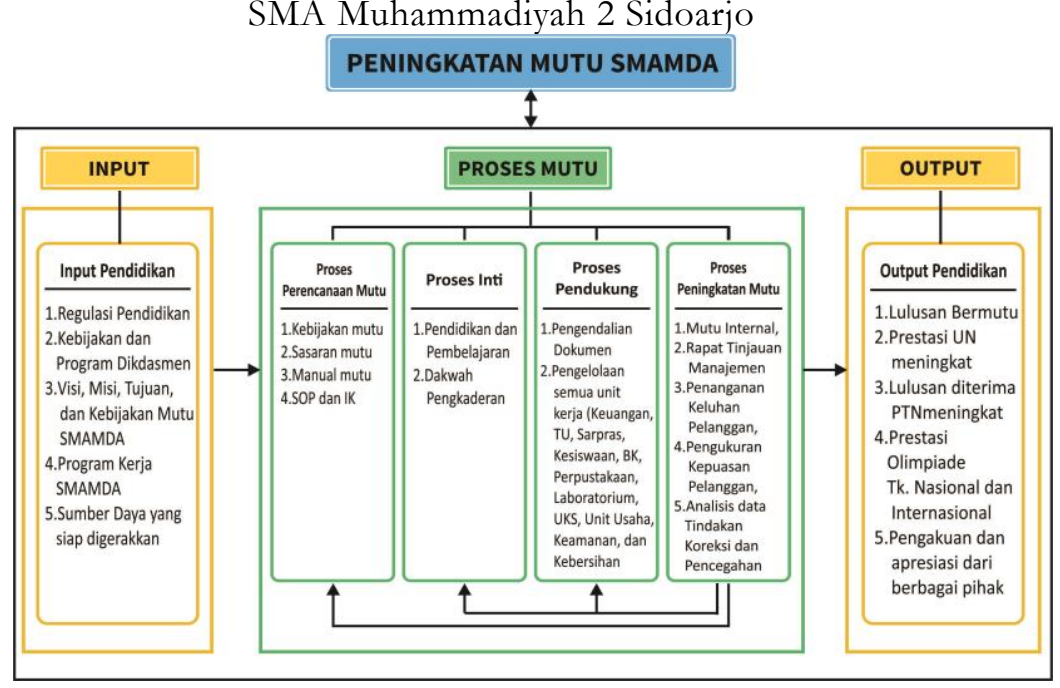

Model manajemen mutu SMA Muhammadiyah 2 Sidoarjo di atas dapat dijelaskan bahwa input pendidikan merupakan sesuatu 
yang harus tersedia dan menjadi dasar bagi proses manajemen mutu. Dari input pendidikan tersebut kemudian dijalankan proses mutu pendidikan, yang berlangsung dalam empat tahapan prosesproses perencanaan mutu, proses inti, proses pendukung, dan proses peningkatan mutu. Proses peningkatan mutu yang meliputi kegiatan audit mutu internal, rapat tinjauan manajemen, penanganan keluhan pelanggan, pengukuran kepuasan pelanggan, analisis data, serta tindakan koreksi dan pencegahan yang diarahkan untuk mengoptimalkan proses inti dan proses pendukung serta memberikan masukan untuk perbaikan perencanaan mutu pendidikan berikutnya. Dari proses mutu tersebut diharapkan menghasilkan output pendidikan yang berutu, sehingga secara keseluruhan mampu meningkatkan mutu pendidikan di SMA Muhammadiyah 2 Sidoarjo.

\section{Keunggulan SMA Muhammadiyah 2 Sidoarjo}

Upaya peningkatan mutu pendidikan di SMA Muhammadiyah 2 Sidoarjo tersebut mampu mengantarkan sekolah ini menjadi sekolah unggulan dengan kategori The Outstanding School of Mubammadiyah. Dalam penelitian ini ditemukan delapan belas indikator atau karakteristik keunggulan SMA Muhammadiyah 2 Sidoarjo, sebagai sekolah barkatagori The Outstanding School of Mubammadiyah, yaitu: (1) Memiliki rumusan visi, misi, tujuan, dan program yang jelas; (2) Memiliki kebijakan mutu yang jelas; (3) Mengembangkan kepemimpinan dan teamwork yang kuat; (4) Memiliki pendidik dan tenaga kependidikan yang kompeten dan berkomitmen tinggi dalam mencapai keunggulan; (5) Memiliki sarana dan prasarana yang lengkap dan didukung oleh sistem informasi manajemen; (6) Menerapkan sistem seleksi dalam penerimaan peserta didik baru; (7) Proses pendidikan dan pembelajaran berlangsung sangat baik; (8) Tersedia pilihan lembaga organisasi dan kegiatan ekatra kurikuler sesuai minat dan bakat peserta didik; (9) Melakukan penguatan karakter dan budaya mutu sekolah; (10) Pemberian beasiswa kepada peserta didik, guru, dan karyawan; (11) Melaksanakan tata kelola keuangan secara sehat; (12) Memperkuat brand sekolah dengan menambah diferensiasi; (13) Partisipasi orang tua peserta didik yang sangat tinggi dalam peningkatan mutu dan pembiayaan pendidikan sangat tinggi; (14) Prestasi dan penghargaan yang dicapai sekolah luar biasa; (15) Lingkungan sekolah yang aman, teratur, dan nyaman; (16) Menerapkan sistem manajemen mutu yang berdampak terhadap perbaikan dan peningkatan mutu sekolah; (17) Berorientasi 
internasional (International orientation); dan (18) Medapat pengakuan dan apresiasi dari berbagai kalangan.

Keunggulan SMA Muhammadiyah 2 Sidoarjo yang digambarkan dengan delapan belas karakteristik sebagaimana disebutkan di atas menunjukkan bahwa ciri-ciri atau indikator keunggulan sekolah ini menyempurnakan temuan atau pendapat beberapa ahli. Beberapa pendapat yang dikemukakan oleh para ahli itu dapat penulis kemukakan di bawah ini.

Chaedar Alwasilah menyebutkan ada tujuh karakteristik pendidikan unggul, yaitu: (1) Visi dan misi sekolah yang jelas; (2) Komitmen tinggi tenaga kependidikan untuk unggul; Kepemimpinan yang mumpuni; (4) kualitas pembelajaran yang unggul; (5) Lingkungan yang aman dan teratur; (6) hubungan yang baik antara rumah dan sekolah; dan (7) Monitoring kemajuan siswa secara berkala. ${ }^{22}$ Dalam pandangan lain Djoyo Negoro menyebutkan enam ciri sekolah unggul, yaitu: (1) Memiliki prestasi akademik dan non-akademik di atas rata-rata sekolah yang ada di daerahnya, (2) Memiliki sarana dan prasarana serta layanan yang lebih lengkap, (3) Memiliki sistem pembelajaran lebih baik dan waktu belajar lebih panjang, (4) Melakukan seleksi yang cukup ketat terhadap pendaftar, (5) Mendapat animo yang besar dari masyarakat, yang dibuktikan banyaknya jumlah pendaftar dibanding dengan kepasitas kelas; dan (6) Biaya sekolah lebih tinggi dari sekolah disekitarnya. ${ }^{23}$

Fullan menyebutkan lima ciri sekolah unggul, yaitu: Kepemimpinan yang tangguh, (2) Administrator dan guru yang mengutamakan pembelajaran dan memberikan waktu yang banyak untuk kepentingan peserta didik, (3) Administrator dan guru memiliki ekspektasi yang tinggi bahwa semua anak dapat meningkatkan prestasi belajarnya, (4) Atmosfir sekolah nyaman dan menyokong pada penguatan pembelajaran, dan (5) Guru memonitor kemajuan anak melalui koleksi data diagnostik dan menggunakan data untuk meningkat-kan pembelajaran. ${ }^{24}$

Secara lebih komprehensif Arief Rachman menyebut sepuluh indikator sekolah unggul, yaitu: (1) Kepemimpinan sekolah yang

\footnotetext{
${ }^{22}$ Muhammad Ali, Menabur Benih Sekolah Unggul di Mubammadiyah (Yogyakarta: Suara Muhammadiyah, 2009), 103.

23 Fahmi Irhamsyah, "Menggagas Sekolah Unggulan", dalam http://edukasi. kompasiana.com/ 2013/03/01/menggagas-sekolah-unggulan-539183.html (3 Mei 2014).

24 Ibid., 87.
} 
profesional; (2) Semua warga sekolah memahami dan melaksanakan visi dan misi sekolah; (3) Suasana pembelajaran yang menyenangkan; (4) Kegiatan pembelajaran di sekolah sangat beragam, seperti intra kurikuler, ko kurikuler, dan ekstra kurikuler berjalan secara seimbang dan saling mendukung; (5) Guru memiliki perencanaan pembelajaran, yang ditunjukkan dengan adanya target yang jelas, terorganisir, dikomunikasikan pada siswa, dan adanya fleksibilitas sesuai dengan kondisi siswa; (6) Semua program yang positif mendapat penguatan dari sekolah, orang tua, dan siswa; (7) Sekolah melakukan monitoring dan evaluasi secara ter-program dan berdampak terhadap perbaikan sekolah; (8) Hak dan kewajiban siswa dipahami dan dilaksanakan dengan baik di sekolah; (9) Kemitraan antara sekolah dengan rumah tangga atau orang tua; dan (10) Munculnya kreativitas dalam organisasi sekolah untuk pengembangan pendidikan. ${ }^{25}$

Keunggulan sekolah di Inggris yang masuk katagori outstanding school digambarkan dengan delapan indikator, yaitu: (1) Kepala sekolah menunjukkan kepemimpinan yang inspiratif; (2) Prestasi yang dicapai oleh peserta didik di berbagai bidang luar biasa; (3) Proses pendidikan dan pembelajaran berlangsung dengan sangat baik; (4) Pendidikan spiritual, moral, dan sosial budaya menjadi dasar dalam me-nanamkan keteladanan peserta didik dalam belajar, sikap dan perilaku mereka; (5) Pendaftaran peserta didik baru mengalami peningkatan yang sangat baik; (6) Setiap bagian memiliki pengetahuan dan keterampilan sangat baik tentang pendidikan dan pembelajaran yang tinggi; (7) Sekolah tidak hanya memberikan kegiatan akademik, tetapi juga berbagai kegiatan non akademik yang menarik, seperti kompetisi dan pertunjukkan; dan (8) Peserta didik merasa sangat aman berada di sekolah dan sangat menikmati semua aspek kehidupan di sekolah". ${ }^{26}$

Upaya peningkatan mutu dan keunggulan yang dicapai oleh SMA Muhammadiyah 2 Sidoarjo tersebut sejalan dengan amanah Pimpinan Pusat Muhammadiyah serta kebijakan dan program peningkatan mutu pendidikan Muhammadiyah. Amanah Pimpinan Pusat Muhammadiyah menyatakan bahwa "Muhammadiyah sebagai organisasi sosial kemasyarakatan sangat konsen dan berkhidmat dalam kerja-kerja untuk: (1) Mempercepat proses pengembangan institusi

\footnotetext{
25 Arief Rachman, "Ada Sepuluh Ciri Sekolah Unggul” dalam http://www.republika .co.id/berita/pendidikan/berita/10/05/18/115906-prof-arief-rachman-adasepuluh-ciri-sekolah-unggul (30 April 2014).

${ }^{26}$ Raising Standars Improving Lives, "School Report, Powell's Church of England Primary School”, dalam http://www.powells.gloucs.sch. (12 Mei 2014), 7.
} 
pendidikan Muhammadiyah sebagai pusat keunggulan dengan menyusun standar mutu, dan (2) Menjadikan mutu sebagai tujuan utama bagi seluruh usaha pengembangan amal usaha pendidikan Muhammadiyah. ${ }^{27}$

Hal di atas juga sejalan dengan cita pendidikan Muhammadiyah yang ingin dicapai, yaitu pendidikan yang berkualitas unggul, maju, modern, dan profesional. $^{28}$ Majelis Dikdasmen Pimpinan Pusat Muhammadiyah merumuskan lima karakteristik pendidikan Muhammadiyah unggul, yaitu: (1) Terbangunnya sistem manajemen organisasi yang efektif, terutama dalam sistem perencanaan, pengendalian, dan evalusi; (2) Tertatanya fungsi, peran, dan kegiatan organisasi otonom; (3) Terbentuknya SDM pelaku dan pengelola yang handal dan berkualitas; (4) Terwujudnya model peran dan jaringan yang luas dan kokoh yang dapat menunjang amal usaha, kegiatan dan perangkat Persyarikatan; dan (5) Terbangunnya kesadaran dan fungsi pelayanan sebagai wahana dakwah untuk mewujudkan masyarakat Islam yang sebenar-benarnya. ${ }^{29}$

Dari berbagai pendapat para ahli dan hasil temuan dalam penelitian di SMA Muhammadiyah 2 Sidoarjo tentang keunggulan sekolah terdapat banyak kesamaan dan sebagian ada yang bebeda, ini bisa jadi karena sudut pandang dan fokus kajiannya yang tidak sama. Dari kesemuanya terdapat irisan yang cukup besar, dan hasil penelitian ini menunjukkan adanya pengembangan dari konsep keunggulan pendidikan yang dikemukakan oleh para ahli sebelumnya.

Keunggulan SMA Muhammadiyah 2 Sidoarjo dengan delapan belas indikator di atas memiliki banyak kesamaan dengan konsep keunggulan sekolah yang dikemukakan oleh para ahli sebelumnya, yang terjadi di-setting penelitian ini menunjukkan adanya pengembangan dari yang sebelumnya. Berbagai keunggulan yang dimiliki itu mampu mengantarkan SMA Muhammadiyah 2 Sidoarjo menjadi sekolah dengan kategori The Outstanding School of Muhammadiyah.

Sejalan dengan Perkembangan SMA Muhammadiyah 2 Sidoarjo dengan berbagai keunggulan di atas, masih menyisakan beberapa persoalan, terutama berkaitan dengan kesempatan dan pemerataan akses pendidikan bermutu. Secara umum SMA Muhammadiyah 2

\footnotetext{
27 Pimpinan Pusat Muhammadiyah, Berita Resmi Muhammadiyah No. 01/2005.

28 Ali, Menabur Benih Sekolah, 103

${ }^{29}$ Ibid.
} 
Sidoarjo terkesan elitis, gedungnya bagus dan modern, fasilitasnya lengkap, dan manajemennya bagus. Meskipun demikian, harus diakui bahwa daya akomodasi sekolah terhadap masyarakat kurang mampu yang ingin menyekolahkan anaknya ke SMA Muhammadiyah 2 Sidoarjo ini tidak bisa terlayani secara keseluruhan, orang tua yang kurang mampu harus berfikir berulangkali mengenai biaya pendidikan yang harus ditanggung ketika mau memasukkan anaknya ke SMA Muhammadiyah 2 Sidoarjo.

Rata-rata orang tua/wali peserta didik yang menyekolahkan anaknya ke SMA Muhammadiyah 2 Sidoarjo ini berasal dari kalangan kelas menengah ke atas dan dari sebagian masyarakat kalangan bawa merasa kurang terfasilitasi, sehingga terasa kurang dalam melakukan praksis emansipatoris sebagai amal usaha Muhammadiyah yang pro terhadap masyarakat kurang mampu. Keadaan ini terkadang menimbulkan kritik tajam dari sebagian masyarakat. Dalam kaitan itu $\mathrm{Mu}$ 'arif mengatakan menguatnya kritik tajam akan stigma elitisme di sebagian amal usaha Muhammadiyah banyak dijumpai di kalangan eksternal maupun internal Muhammadiyah, sebab pada mulanya gerakan Muhammadiyah ini adalah gerakan di sosial kemasyarakatan, misalnya sekolah-sekolah, didirikan dengan tujuan untuk membantu masyarakat umum, dan khususnya umat Islam, yang berada dalam kondisi kemiskinan dan keterpurukan. Tujuan gerakan Muhammadiyah adalah untuk menyejahterahkan umat". ${ }^{30}$ Lebih lanjut Mu'arif menyatakan bahwa salah satu risiko terbesar ketika amal usaha dijalankan dengan manajemen profesional adalah berimbas pada diterapkannya sistem kapitalis, karena manajamen profesional itu tidak murah biayanya. Dari sinilah kemudian gerakan Muhammadiyah terkesan sangat elitis. ${ }^{31}$

Menjawab kritik di atas SMA Muhammadiyah 2 Sidoarjo menerapkan kebijakan pemberian kuota beasiswa bidik misi (dibebaskan dari seluruh biaya pendidikan) bagi peserta didik yang memenuhi kriteria dan pemberian beasiswa untuk peserta didik dari keluarga kurang mampu. Jumlah kuota bidikmisi yang disediakan masih terlalu sedikit dan kurang menyebar, karena salah satu persyaratan untuk bisa menerima bidik misi adalah harus melampirkan surat rekomendasi dari pimpinan Persyarikatan Muhammadiyah,

\footnotetext{
${ }^{30}$ Mu'arif, Menepis Stigma Elitisme Gerakan Mubammadiyah (Yogyakarta: Pustaka SM, 2006), 74 .

${ }^{31}$ Ibid., 77.
} 
akibatnya orang yang tidak mempunyai akses ke Muhammadiyah akan mengalami kesulitan untuk mendapatkan surat rekomendasi bidik misi. Selain itu SMA Muhammadiyah 2 Sidoarjo juga memberikan beasiswa pendidikan bagi keluarga tidak mampu di luar bidik misi, dimana besaran beasiswa yang diberikan bergantung dari hasil telaah yang dilakukan oleh sekolah, bergerak antara 25\% sampai dengan $75 \%$ dari biaya pokok pendidikan. ${ }^{32}$

Memperhatikan rumusan visi, misi, tujuan, kebijakan dan program Majelis Dikdasmen tentang peningkatan mutu pendidikan Muhammadiyah di Jawa Timur, maka pengelolaan pendidikan Muhammadiyah harus dilakukan dengan profesional dan diorientasikan kepada pendidikan berkeunggulan, berkarakter, dan berdaya saing tinggi. Meskipun demikian, pedidikan Muhammadiyah tidak boleh meninggalkan kebutuhan masyarakat kelas bawah untuk dapat menikmati layanan pendidikan bermutu di Muhammadiyah. Pendidikan Muhammadiyah tidak boleh melahirkan jurang pemisah antara masyarakat kelas bawah dengan masyarakat kelas menengah dan atas, harus mampu membangun kebersamaan antara yang mampu dengan yang kurang mampu, sehingga ada keberpihakan pada masyarakat yang kurang mampu. Hal ini sejalan dengan isi pendidikan Islam menurut K.H. Ahmad Dahlan, yaitu: iman, cinta sesama dan pemihakan pada orang sengsara, tingkat perbedaan terendah adalah asas kebersamaan, pengembangan rasa tanggung jawab dan penyerahan, mengembangkan kemampuan berpikir, dan pengendalian diri. $^{33}$

Dalam perkembangannya, dari waktu ke waktu biaya pendidikan mengalami peningkatan terus, hal ini bisa dimaklumi bahwa untuk mewujudkan pendidikan bermutu diperlukan dukungan dana yang tidak kecil. Secara umum sekolah yang bermutu bisa dipastikan biaya pendidikannya tinggi, karena kebutuhan biaya operasional dan pengembangan sekolah yang juga besar. Persoalannya adalah bagaimana anak-anak dari keluarga kurang mampu itu masih mempunyai kesempatan untuk mendapatkan layanan pendidikan bermutu pula. Dalam kaitan ini perlu dicarikan jalan keluarnya bahwa pemberian beasiswa perlu diperbanyak dan sumber pendanaannya tidak harus dari sekolah, tetapi pengurus Muhammadiyah yang

\footnotetext{
32 Wigatiningsih, Wawancara, Sidoarjo, 27 Juli 2015.

33 Agus Wibowo, "Muhammadiyah dan Pendidikan Kaum Tertindas" dalam http:/ / agus82.wordpress.com, (12 November 2008).
} 
membawai sekolah tersebutu mencarikan atau memberikan beasiswa yang dibutuhkan, misalnya memberdayakan LAZISMU (Lembaga Amil Zakat, Infaq, dan Sedekah Muhammadiyah) untuk menjadi penopang utama dalam pembiayaan pendidikan bagi anak-anak dari keluarga kurang mampu.

\section{Penutup}

Upaya peningkatan mutu SMA Muhammadiyah 2 Sidoarjo diwujudkan dalam 15 langkah di atas, jika dikaitkan dengan karyakarya sebelumnya, maka kita akan menemukan beberapa kesamaan dan perbedaan. Zamroni menyatakan bahwa peningkatan mutu pendidikan di tingkat sekolah dan kelas dapat dicapai dengan menjalankan delapan langkah, yaitu: (1) Melakukan school review; (2) Menyusun visi, misi, strategi, dan program kerja; (3) Memperluas kepemimpinan partisipatif; (4) Melakukan intervensi pada berbagai level; (5) Mengembangkan kultur sekolah; (6) Meningkatkan kemampuan guru; (7) Memobilisasi sumber dana; dan (8) Melakukan monitoring dan evaluasi. ${ }^{34}$ Dari delapan langkah yang dikemukakan oleh Zamroni tersebut semuanya ada kesamaan dengan upaya peningkatan mutu pendidikan di SMA Muhammadiyah 2 Sidoarjo, kecuali pada poin (4) yang tidak ada, yaitu melakukan intervensi pada berbagai level.

Dalam perspektif yang berbeda, Syafaruddin menyatakan bahwa peningkatan mutu pendidikan di tingkat sekolah dapat dicapai dengan melakukan delapan hal juga, yaitu: (1) Menyamakan komitmen mutu oleh kepala sekolah; (2) Mengusahakan adanya program peningkatan mutu sekolah; (3) Meningkatkan pelayanan administrasi sekolah; (4) Kepemimpinan kepala sekolah yang efektif; (5) Ada standar mutu lulusan; (6) Jaringan kerja sama yang baik dan luas; (7) Penataan organisasi sekolah yang baik; dan (8) Menciptakan iklim dan budaya sekolah yang kondusif. ${ }^{35}$ Dalam konteks ini upaya peningkatan mutu pendidikan di SMA Muhammadiyah 2 Sidoarjo merupakan pengembangan dari karya Syafaruddin.

Upaya peningkatan mutu SMA Muhammadiyah 2 Sidoarjo di atas juga mempunyai kesamaan dengan konsep sekolah bermutu yang dirumuskan oleh Kemendiknas, yang menyatakan bahwa proses pendidikan yang bermutu memiliki 14 karakteristik, yaitu: (1) Efektivitas proses belajar mengajar tinggi, (2) Kepemimpinan sekolah

34 Zamroni, Meningkatkan Mutu Sekolah, 91-92.

35 Syafaruddin, Manajemen Lembaga, 288. 
yang kuat, (3) Pengelolaan tenaga kependidikan secara efektif, (4) Sekolah memiliki lingkungan yang aman dan tertib, (5) Sekolah memiliki budaya mutu, (6) Sekolah memiliki teamwork yang kompak, cerdas, dan dinamis, (7) Sekolah memiliki kemandirian, (8) Partisipasi yang tinggi dari warga sekolah dan masyarakat, (9) Sekolah memiliki transparansi manajemen, (10) Sekolah memiliki kemauan untuk berubah, (11) Sekolah melakukan evaluasi dan perbaikan secara berkelanjutan, (12) Sekolah responsif dan antisipatif terhadap kebutuhan, (13) Sekolah memiliki komunikasi yang baik, dan (14) Sekolah memiliki akuntabilitas. ${ }^{36}$

Dari konsep peningkatan mutu pendidikan yang dikemukakan oleh Zamroni, Syafaruddin, dan Kemendiknas tersebut terdapat irisan yang menunjukkan adanya kesesuaian dengan upaya peningkatan mutu SMA Muhammadiyah 2 Sidoarjo, bahkan merupakan pengembangan dari karya-karya tentang peningkatan mutu pendidikan yang ada sebelumnya.

\section{Daftar Rujukan}

Ali, Muhammad. Menabur Benih Sekolah Unggul di Mubammadiyah. Yogyakarta: Suara Muhammadiyah, 2009.

Biyanto (Ketua Majelis Dikdasmen PW Muhammadiyah Jawa Timur). Wawancara. Surabaya, 15 November 2013.

Delasera, Qori. "Kualitas Pendidikan Indonesia (Refleksi 2 Mei)", dalam http://edukasi.kompasiana. com/ 2013/05/03/kualitaspendidikan-indonesia-refleksi-2-mei-html (16 Januari 2014).

Departemen Pendidikan Nasional. Manajemen Peningkatan Mutu Berbasis Sekolah, Konsep dan Pelaksanaan. Jakarta: Dirjen Dikdasmen, 2001.

Depdiknas. Panduan Manajemen Sekolah. Jakarta: Dirjen Dikdasmen, 2000.

Fadjar, Abdul Malik. "Pengembangan Pendidikan Islam Yang Menjanjikan Masa Depan”, dalam Mudjia Rahardjo (ed.), Quo Vadis Pendidikan Islam, Pembacaan Realitas Pendidikan Islam, Sosial, dan Keagamaan. Malang: UIN Malang Press, 2006.

Fathoni, AB. Musyafa'. "Peningkatan Kualitas Pendidikan Melalui Sistem Penjaminan Mutu: Studi Multisitus di SD Al Falah Tropodo 2 Sidoarjo, SDIT Bina Insani Kediri, dan SDIT AlHikmah Blitar". Disertasi--Program Studi Manajemen Pendidikan, Program Pascasarjana Universitas Negeri Malang, 2009.

${ }^{36}$ Depdiknas, Panduan Manajemen Sekolah, 25-26. 
Irhamsyah, Fahmi. "Menggagas Sekolah Unggulan", dalam http://edukasi.kompasiana.com/2013/03/01/menggagas-sekol ah-unggulan-539183.html (3 Mei 2014).

Karwanto. "Ketrampilan Manajerial Peningkatan Keunggulan Pembelajaran: Studi Multi Kasus pada Tiga SMA Unggulan di Kota Semarang". Disertasi--Program Studi Manajemen Pendidikan, Program Pascasarjana Universitas Negeri Malang, 2009.

Kopertis Wilayah XII, "Skor PISA: Posisi Indonesia Nyaris Jadi Juru Kunci", dalam http://www.kopertis12.or.id/2013/12/05/skorpisa-posisi-indonesia-nyaris-jadi-juru-kunci.html (7 Maret 2014).

Mu'arif. Menepis Stigma Elitisme Gerakan Mubammadiyah. Yogyakarta: Pustaka SM, 2006.

Pimpinan Pusat Muhammadiyah, Berita Resmi Mubammadiyah No. 01/2005.

Rachman, Arief. "Ada Sepuluh Ciri Sekolah Unggul" dalam http://www.republika.co.id/berita/pendidikan/berita/10/05/18 /115906-prof-arief-rachman-ada-sepuluh-ciri-sekolah-unggul (30 April 2014).

Raising Standars Improving Lives, "School Report, Powell's Church of England Primary School", dalam http://www.powells.gloucs .sch. 12 Mei 2014.

Sallis, Edward. Total Quality Management in Education. London: Kogan Page, 1993.

SMA Muhammadiyah 2 Sidoarjo, Manual Mutu. Sidoarjo: Lembaga Penjaminan Mutu, 2013.

Supriyanto, Achmad. "Implementasi Total Quality Management dalam Sistem Manajemen Mutu Pembelajaran di Institusi Pendidikan”, Cakrawala Pendidikan: Jurnal Ilmiah Pendidikan, Vol. 30, No. 1, 2011. Syafaruddin. Manajemen Lembaga Pendidikan Islam. Jakarta: Ciputat Press, 2005.

Uchtiawati, Sri. "Penjaminan Mutu Pendidikan pada Perguruan Tinggi Muhmmadiyah di Jawa Timur: Studi Multisitus pada Universitas Sukiyanto, Universitas Suherman, dan Universitas Madjedi”. Disertasi--Program Studi Manajemen Pendidikan Program Pascasarjana Universitas Negeri Malang, 2010.

Wibowo, Agus. "Muhammadiyah dan Pendidikan Kaum Tertindas" dalam http://agus82.wordpress.com, (12 November 2008).

Wigatiningsih. Wawancara. Sidoarjo, 27 Juli 2015. 
Hidayatulloh

Yunus, Falah. "Manajemen Peningkatan Mutu Pendidikan", dalam http://www. geocities.ws/guruvalah/ Manaj Pening Mutu Pend.html 6 April 2014.

Zamroni. Meningkatkan Mutu Sekolah, Teori, Strategi, dan Prosedur. Jakarta: PSAP Muhammadiyah, 2007. 